severely disabled patients. This could be interpreted in terms of advanced striatal disease leading to increased denervation supersensitivity. Alternatively, this finding may simply derive from greater room for improvement by a dopaminergic agonist because in patients with gross disease there is substantial depletion of striatal L-aromatic aminoacid decarboxylase and so a more limited response to levodopa.

Dopaminergic agonists, however, also carry certain theoretical disadvantages. Accumulating evidence indicates that these drugs tend to decrease the release of dopamine by a control system involving presynaptic receptors (Farnebo and Hamberger, 1973) and a negative feed-back loop (Walters et al., 1974). Most of our patients were taking levodopa, and presumably maintaining a certain level of therapeutic response by dopamine release. The fact that further improvement was obtained with a dopamine agonist suggests that if this drug reduces dopamine output the consequences are of minor importance. Nevertheless, it would clearly be of interest to establish the relative therapeutic potency of bromocriptine with and without concomittant administration of levodopa. Another important area for further investigation is the possible potentiation of bromocriptine by simultaneous administration of a phosphodiesterase inhibitor such as caffeine or theophylline since these agents would be expected to delay the destruction of cyclic adenosine monophosphate formed in striatal neurons as the result of dopaminergic activation (Kebabian et al., 1972).

We thank Dr. G. Curzon for biochemical analysis of the C.S.F. and Sandoz Ltd. for the supply of bromocriptine. We thank Miss E. Allbutt and Mrs. C. Chmaj for administrative help. This work was supported by the Medical Research Council.

\section{References}

Corrodi, H., et al. (1973). Fournal of Pharmacy and Pharmacology, 25, 409. Cotzias, G. C., et al. (1970). New England Fournal of Medicine, 282, 31.

Farnebo, L. O., and Hamberger, B. (1973). In Frontiers in Catecholamine Research, ed. S. H. Snyder, and E. Usdin. New York, Pergamon Press. Kebabian, J. W., Petzold, G. L., and Greengard, P. (1972). Proceedings of the National Academy of Sciences of the U.S.A., 69, 2145.

Lloyd, K. G., and Hornykiewicz, O. (1970). Science, 170, 1212.

Pozo, E. del, and Flückiger, E. (1973). In Human Prolactin, ed. J. L. Pasteels and C. Robyn. Amsterdam, Excerpta Medica.

Vakil, S. D., et al. (1973). In Progress in the Treatment of Parkinsonism, Advances in Neurology, Vol. 3., ed. D. B. Calne, p. 121. New York, Raven Press.

Walters, J. R., Bunney, B. S., and Roth, R. H. (1974). In Dopaminergic Mechanisms, Advances in Neurology, vol. 5 , ed. D. B. Calne, T. N. Mechanisms, Advances in Neurology, vol. 5 , ed.

Yahr, M. D. (editor) (1973). The Treatment of Parkinsonism-The Role of Dopa Decarboxylase Inhibitors, Advances in Neurology, vol. 2. New York, Raven Press.

\title{
New Approach to Assessment of Cardioselectivity of Beta-blocking Drugs
}

\author{
C. R. KUMANA, \\ G. E. MARLIN, \\ C. M. KAYE, \\ D. M. SMITH
}

British Medical fournal, 1974, 4, 444-447

\section{Summary}

Propranolol, practolol, and placebo were each given intravenously at weekly intervals to six normal subjects, and their effects on respiratory function tests and heart rates assessed. The reduction in the exercise heart rate after each of the two drugs was most comparable at six hours, indicating a similar degree of cardiac beta-blockade, when the plasma concentration ratio of practolol to propranolol was 28:1. The peak flow rate (PFR) was higher at all times during exercise than at rest. There were significant differences between the changes in resting and exercise PFR after placebo and the reductions after propranolol (except at 24 hours), but not after practolol-and the latter's influence on PFR seemed to be intermediate to that of propranolol and placebo. At six hours, when the cardiac beta-blocking activity of the two drugs was almost the same, there was a significant difference ( $P$ 0.025) between the reductions in exercise PFR associated with each drug.

\section{St. Bartholomew's Hospital, London EC1A 7BE}

C. R. KUMANA, M.B., M.R.C.P., Clinical Research Fellow, Department of

G. E. MARLIN, M.B., M.R.A.C.P., Honorary Research Fellow, Department

C. M. KAYE, PH.D., A.R.I.C., Research Biochemist, Department of Clinical C. M. RAYE, PH.

D. M. SMITH, M.sc., Statistician, Computing Unit for Mediral Sciences

Small though significant differences $(P<0.05)$ were found only between the changes in FEV $_{1}$ after placebo and the reductions after each drug at one, two, and three hours, and there was no significant difference beween the effects of the two drugs. This study supported the suggestion that betasympathetic stimulation contributes to the bronchodilatation evident during exercise. Moreover, it emphasizes the importance of assessing airway resistance both at rest and during exercise and of comparing the pulmonary effects of different drugs when their cardiac beta-blocking activity is equivalent.

\section{Introduction}

The extent to which commonly used beta-blocking drugs affect ainway resistance in normal adults is controversial (McNeill, 1971). The relative cardiac and bronchopulmonary activity of such drugs is usally assessed by giving arbitrary doses of each drug and determining their effects at arbitrary fixed times after administration. Clinically, however, it may be more important to compare unwanted side effects such as bronchoconstriction at times when desirable cardiac effects are similar.

Beta-adrenoceptor blocking drugs produce little or no slowing of resting heart rate but greatly reduce that during strenuous exercise (Robinson et al., 1966). This has been taken as evidence that beta-sympathetic stimulation of the heart increases with exercise, and hence a useful index of cardiac beta-blocking activity is how much the heart rate associated with vigorous exercise is reduced. By analogy, if the bronchodilatation accompanying exercise (Jones et al., 1962) is also due to sympathetic stimulation, the effect of 
beta-blocking drugs on airway resistance might also be more apparent during exercise than at rest.

This study therefore compared the effects of propranolol and practolol on airway resistance both at rest and during exercise at times when their effects on exercise heart rate were similar. It also aimed to determine the plasma concentration ratio at which the effects of the two drugs on exercise heart rate would be the same.

\section{Subjects and Methods}

The subjects in this investigation were six healthy men normotensive volunteers aged 20-36 none of whom had a history of asthma. All had normal E.C.G.s. The three treatments $(0.3$ $\mathrm{mg} / \mathrm{kg}$ propranolol, $2 \mathrm{mg} / \mathrm{kg}$ practolol, and saline) were given intravenously over 10 minutes to every subject, each treatment being given at weekly intervals. The whole study was double blind, balanced, and randomized. The subjects exercised for three minutes on a Monark bicycle ergometer before and at one, two, three, four, six, and 24 hours after each treatment, the exercise sessions ending on the hour. The cycling was against a fixed load $(1,200 \mathrm{kpond} \mathrm{m} / \mathrm{min}$ for five subjects and $1,350 \mathrm{kpond} \mathrm{m} / \mathrm{min}$ for the remaining subject), shown in preliminary studies on each individual to be the smallest load (to the nearest $150 \mathrm{kpond} \mathrm{m} / \mathrm{min}$ ) to produce heart rates of over 160 beats/min on cycling for three minutes.

Before each period of exercise the subjects rested for five minutes, after which the heart rate was recorded over 30 seconds with an electrocardiograph. Resting peak flow rate (PFR; mean of three readings) and forced expiratory volume in 1 second $\left(\mathrm{FEV}_{1}\right.$; highest of three readings) were determined using a Wright peak flow meter and vitalograph respectively. During exercise five PFR readings were taken and the mean of the three highest was determined. The heart rate during the last 30 seconds of exercise was also measured. The results obtained after each treatment were expressed as differences from the pretreatment values and these differences were submitted to analysis of variance. Immediately after each period of exercise venous blood samples were obtained for determination of plasma levels of practolol spectrophotometrically (Turner et al., 1971) and those of propranolol fluorimetrically (Shand et al., 1970).

\section{Results}

The mean heart rate and PFR results are shown in figs. 1 and 2. The changes in PFR and $F_{E V}$ from pretreatment values are shown in figs. 3 and 4 . Statistical analysis followed the standard lines for randomized blocks as outlined by

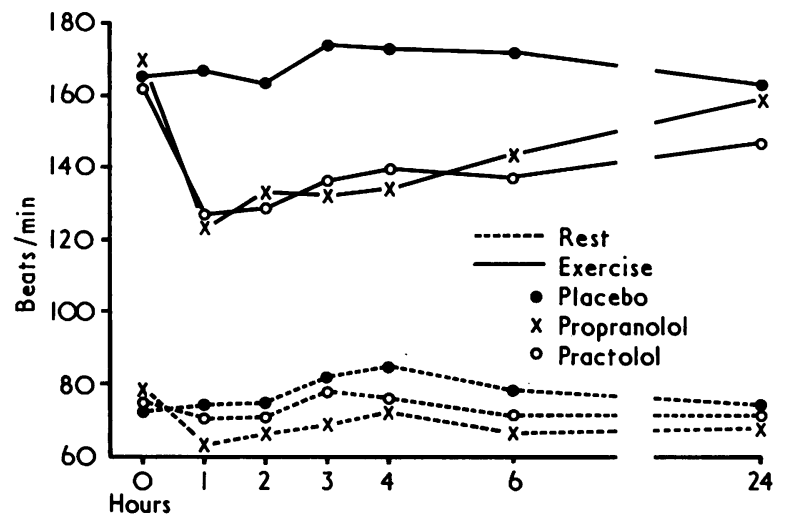

FIG. 1-Mean heart rates of six subjects before (time 0 ) and at various times after three treatments.

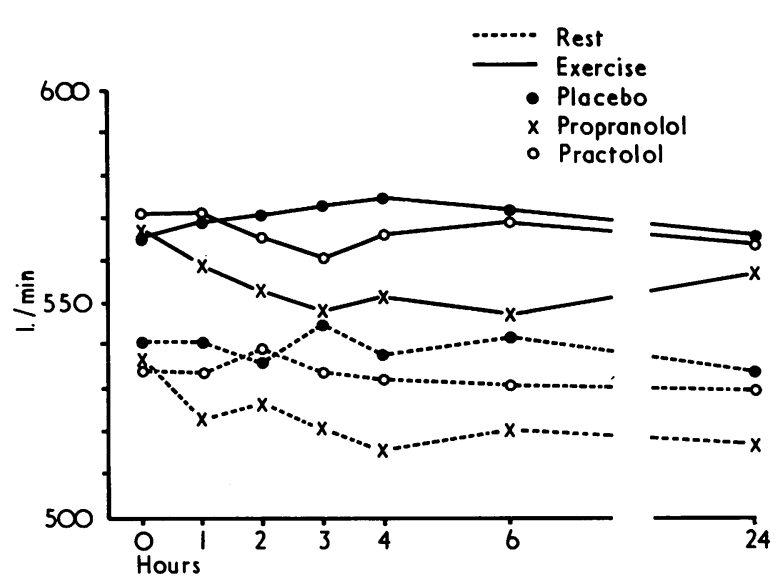

FIG. 2-Mean peak flow rates of six subjects before (time 0) and at various times after three treatments. Note that exercise PFR increased after placebo. Exercise PFR after propranolol approached resting PFR after placebo.

Kempthorne (1952). In each analysis of variance the treatment sum of squares was broken down into various comparisons between the treatments. The results for the comparisons which were of interest are given in the table.

The six subjects had mean plasma propranolol concentrations of $0.095 \mu \mathrm{g} / \mathrm{ml}, \quad 0.069 \mu \mathrm{g} / \mathrm{ml}, \quad 0.054 \mu \mathrm{g} / \mathrm{ml}$, $0.043 \mu \mathrm{g} / \mathrm{ml}$, and $0.026 \mu \mathrm{g} / \mathrm{ml}$ at one, two, three, four, and six hours respectively. Propranolol was not detected in the plasma of any subject at 24 hours-that is, levels were less than $0.010 \mu \mathrm{g} / \mathrm{ml}$. The mean plasma practolol concentrations were $1.38 \mu \mathrm{g} / \mathrm{ml}, 1.10 \mu \mathrm{g} / \mathrm{ml}, 1.02 \mu \mathrm{g} / \mathrm{ml}, 0.94 \mu \mathrm{g} / \mathrm{ml}$.,

\begin{tabular}{|c|c|c|c|c|c|c|c|c|}
\hline & & & \multicolumn{6}{|c|}{$P$ at: } \\
\hline & & & $1 \mathrm{hr}$ & $2 \mathrm{hr}$ & $3 \mathrm{hr}$ & $4 \mathrm{hr}$ & $6 \mathrm{hr}$ & $24 \mathrm{hr}$ \\
\hline $\begin{array}{l}\text { Placebo rest } v \text {. propranolol rest } \ldots \\
\text { Placebo exercise } v \text {. propranolol exercise } \\
\text { Placebo rest } v \text {. practolol rest } \\
\text { Placebo exercise } v \text {. practolol exercise } \quad \ldots \\
\text { Propranolol rest } v \text {. practolol rest } \\
\text { Propranolol exercise } v \text {. practolol exercise }\end{array}$ & $\begin{array}{l}\because \\
\because \\
\because \\
\because\end{array}$ & $\begin{array}{l}\because \\
\because \\
\because \\
\because\end{array}$ & $\begin{array}{l}0.001 \\
0.001 \\
\text { N.S. } \\
0.001 \\
0.025 \\
0.025\end{array}$ & $\begin{array}{r}\text { Heart Rate } \\
0.001 \\
0.001 \\
\text { N.S. } \\
0.001 \\
0.05 \\
\text { N.S. }\end{array}$ & $\begin{array}{l}0.001 \\
0.001 \\
0.05 \\
0.001 \\
0.005 \\
\text { N.S. }\end{array}$ & $\begin{array}{l}0.001 \\
0.001 \\
0.025 \\
0.001 \\
\text { N.S. } \\
0.05\end{array}$ & $\begin{array}{l}0.001 \\
0.001 \\
0.025 \\
0.001 \\
\text { N.S. } \\
\text { N.S. }\end{array}$ & $\begin{array}{l}\text { N.S. } \\
\text { N.S. } \\
\text { N.S. } \\
\text { 0.01 } \\
\text { N.S. } \\
\text { N.S. }\end{array}$ \\
\hline $\begin{array}{l}\text { Placebo rest } v \text {. propranolol rest } \ldots \\
\text { Placebo exercise } v \text {. propranolol exercise } \\
\text { Placebo rest } v \text {. practolol rest } \\
\text { Placebo exercise } v \text {. practolol exercise } \quad \ldots \\
\text { Propranolol rest } v \text {. practolol rest } \ldots \\
\text { Propranolol exercise } v \text {. practolol exercise }\end{array}$ & $\begin{array}{l}\because \\
\because \\
\cdots \\
\cdots\end{array}$ & $\begin{array}{l}\because \\
\because \\
\because \\
\because\end{array}$ & $\begin{array}{l}0.025 \\
0.05 \\
\text { N.S. } \\
\text { N.S. } \\
0.05 \\
\text { N.S. } \\
\text { Forced }\end{array}$ & $\begin{array}{l}\text { N.S. } \\
\text { 0.05 } \\
\text { N.S. } \\
\text { N.S. } \\
\text { N.s. } \\
\text { N.S. }\end{array}$ & $\begin{array}{l}0.05 \\
0.025 \\
\text { N.S. } \\
\text { N.S. } \\
\text { N.S. } \\
\text { N.S. }\end{array}$ & $\begin{array}{l}0.025 \\
0.01 \\
\text { N.S. } \\
\text { N.S. } \\
0.025 \\
\text { N.S. }\end{array}$ & $\begin{array}{l}0.025 \\
0.005 \\
\text { N.S. } \\
\text { N.S. } \\
\text { N.S. } \\
0.025\end{array}$ & $\begin{array}{l}\text { N.S. } \\
\text { N.S. } \\
\text { N.S. } \\
\text { N.S. } \\
\text { N.S. } \\
\text { N.S. }\end{array}$ \\
\hline $\begin{array}{l}\text { Placebo rest } v \text {. propranolol rest } \ldots \\
\text { Placebo rest } v \text {. practolol rest } \\
\text { Propranolol rest } v \text {. practolol rest } \ldots\end{array}$ & $\because$ & $\because$ & $\begin{array}{l}0.01 \\
0.05 \\
\text { N.S. }\end{array}$ & $\begin{array}{l}0.025 \\
0.025 \\
\text { N.S. }\end{array}$ & $\begin{array}{l}0.05 \\
0.05 \\
\text { N.S. }\end{array}$ & $\begin{array}{l}\text { N.S. } \\
\text { N.S. } \\
\text { N.S. }\end{array}$ & $\begin{array}{l}\text { N.S. } \\
\text { N.S. } \\
\text { N.S. }\end{array}$ & $\begin{array}{l}\text { N.S. } \\
\text { N.S. } \\
\text { N.S. }\end{array}$ \\
\hline
\end{tabular}




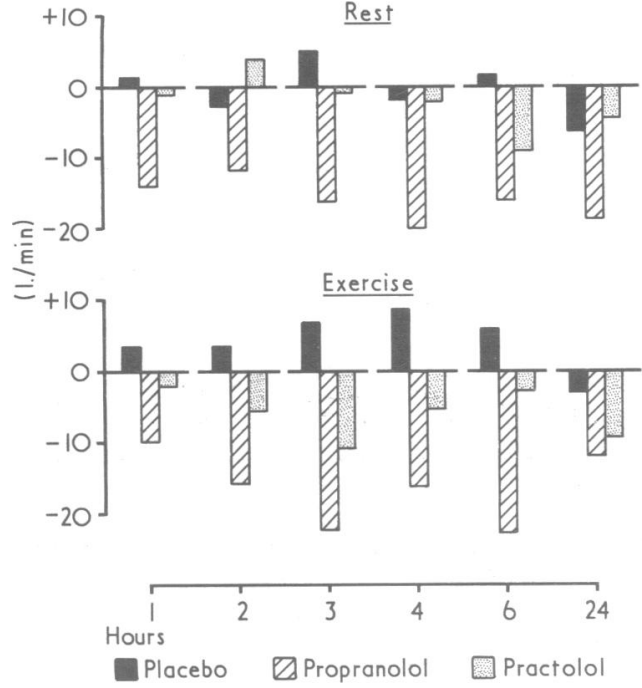

FIG. 3-Mean changes in peak flow rate from pretreatment values in six subjects at various times after three treatments. Blocks above baseline represent increases in PFR and those below represent reductions.
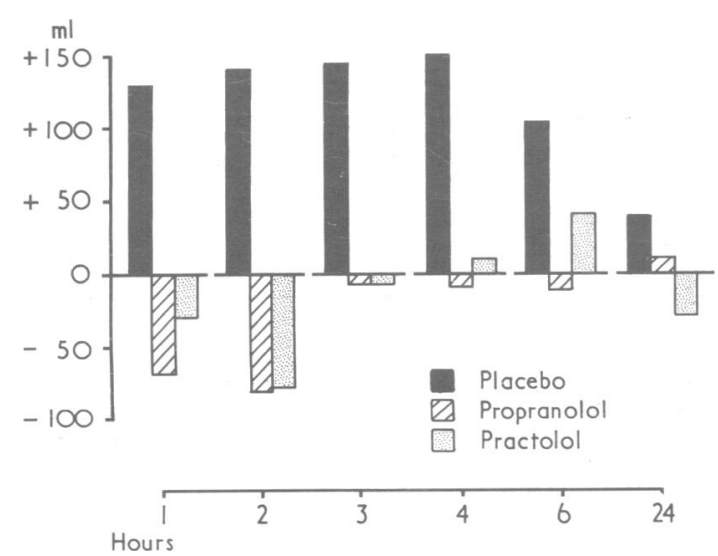

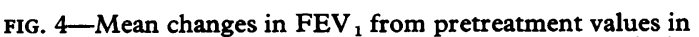
six subjects at various times after three treatments. Blocks above baseline represent increases in FEV 1 and those below represent reductions. Note that after placebo the increases in $\mathrm{FEV}_{1}$ were greater than the reductions after the drug.

$0.72 \mu \mathrm{g} / \mathrm{ml}$, and $0.12 \mu \mathrm{g} / \mathrm{ml}$ at one, two, three, four, six, and 24 hours respectively.

\section{Discussion}

There were several reasons for administering the treatments intravenously. Firstly, 4-OH propranolol, an active metabolite (Fitzgerald and O'Donnell, 1971), is formed only after oral administration of propranolol (Paterson et al., 1970; Coltart and Shand, 1970) and therefore could not influence the relation between the plasma level of propranolol and its effect noted in this study. Secondly, with repeated oral administration of the parent drug (as during routine maintenance treatment) the cardiac beta-blocking effects associated with a plasma concentration correspond with those found after single intravenous injections (Cleaveland and Shand, 1972), as though the effects due to metabolites had disappeared, providing a further reason for obtaining data after single intravenous doses rather than single oral doses. Another reason for avoiding the formation of 4-OH propranolol was that it possesses intrinsic sympathomimetic activity (I.S.A.; Fitzgerald and O'Donnell, 1971). As propranolol, unlike practolol, possesses virtually no I.S.A. only after intravenous administration could a comparison between the effects of the two drugs be considered to be between one with agonist properties and one without. Hence it is possible to test the hypothesis that drugs with agonist activity have no net effect at rest when sympathetic tone is relatively low but have an appreciable effect during exercise when sympathetic tone increases.

Propranolol, which has no I.S.A., consistently reduced resting and exercise heart rates. The most comparable reductions in exercise heart rates occurred at six hours, indicating that the two drugs were producing similar cardiac betablockade. The plasma concentration ratio of practolol to propranolol at that time was $28: 1$. At six hours, the distribution of the two drugs being virtually complete (Paterson et al., 1970; Carruthers et al., 1974), the relationships between their plasma concentrations and their effects were more likely to be stable. Also, by six hours the fluctuations in the plasma practolol decay curves and which have been reported by others (Carruthers et al., 1973) were less apparent. The plasma concentration ratio of about $28: 1$ should hold true over different degrees of submaximal cardiac beta-blockade since Coltart and Shand (1970), Carruthers et al. (1974), and Kumana and Kaye (1974) have shown that the reduction in exercise heart rate produced by each drug is proportional to the logarithm of its plasma concentration. Moreover, the ratio obtained in this study corresponds closely with the ratio of 25:1 reported by Bodem et al. (1973).

Several studies have assessed the influence of propranolol and practolol on airway resistance in normal subjects. They have involved intravenous and oral routes of administration, measurements of $\mathrm{FEV}_{1}$ and specific airway conductance, as well as observations on histamine- or acetylcholine-induced bronchoconstriction. Such studies have shown little agreement and a wide variation in the individual response to these drugs (Zaid and Beall, 1966; MacDonald et al., 1967; Marcelle et al., 1968; Richardson and Sterling, 1969; Turner et al., 1971; Nicolaescu et al., 1973; Ziskind et al., 1973; Kumana and Kaye, 1974). Hence there was a need for a more sensitive method of assessing effects on airway resistance. We decided to investigate airway resistance not only at rest but also during exercise. Any changes occurring in the results of the tests of forced expiration were taken to indicate changes in airway resistance.

The PFR was always greater during exercise than at rest and the increase in PFR during exercise tended to be smaller after the administration of either drug. These obervations supported the assumption that the bronchodilatation occurring during vigorous exercise involved a degree of betasympathetic stimulation. Propranolol, which has no I.S.A., consistently reduced resting and exercise PFR as judged by significant differences between these reductions and the changes in PFR after placebo (see fig. 3 and table); moreover, the bronchodilatation evident during exercise was almost completely blocked (see fig. 2). After practolol, however, the corresponding differences did not attain significant levels, there being no obvious change in resting PFR though there was an overall trend for the exercise PFR to fall (see table and fig. 3). Furthermore, consistent with practolol having an effect intermediate to that of propranolol and placebo, there was usually no significant difference between the two drugs in the reduction in exercise PFR (see table). At six hours, when the cardiac beta-blocking activities of propranolol and practolol were most similar, there was a significant difference $(P<0.025)$ between the reduction in exercise PFR associated with each drug. These data thus confirm the cardioselectivity of practolol as compared to propranolol and also lend support to the suggestion of Connolly and Batten (1970) that I.S.A. might be a factor in the occurrence of cardioselectivity.

The greatest changes in $\mathrm{FEV}_{1}$ were the increases after 
placebo. Unlike the PFR data the $\mathrm{FEV}_{1}$ results showed no significant differences (see table) after three hours and at no time was there a significant difference between the effects of the two drugs. These results suggest that $\mathrm{FEV}_{1}$ and PFR measurements may not reflect identical aspects of airway resistance though generally they correlate well (Pride, 1971). They also indicate that when investigating cardioselectivity airway resistance should be assessed both at rest and during exercise.

Unlike the sympathetic stimulation induced by isoprenaline that occurring during exercise is physiological. Thus using exercise to assess beta-blocking activity is more likely to be clinically relevant except in the rare instances when beta-blocking drugs are used to counteract the effects of administered beta-agonists. Beta-blocking activity, as represented by reduction in exencise heart rate, may not parallel other criteria of cardiac beta-blockade so that equivalent cardioeffective concentrations of propranolol and practolol as determined in this study may not always be appropriate. Nevertheless, the results suggest that when either drug could be used to treat a cardiac disorder practolol is likely to have a less adverse effect on airway resistance than propranolol. This advantage of practolol may also be relevant in impending heart failure since any extra burden on ventilation may exacerbate the symptoms.

We thank the board of governors of St. Bartholomew's Hospital, the postgraduate committee in medicine, the University of Sydney, and the British Heart Foundation for financial support and I.C.I.
Ltd. for supplying propranolol and practolol. We appreciate the help and advice of Professor Paul Turner and Dr. John Hamer.

Requests for reprints should be sent to Dr. Marlin.

\section{References}

Bodem, G., et al. (1973). Fournal of Clinical Investigation, 52, 747.

Carruthers, S. G., et al. (1973). British Medical fournal, 2, 177.

Carruthers, S. G., et al. (1974). Clinical Pharmacology and Therapeutics, 15, 497.

Cleaveland, C. R., and Shand, D. G. (1972). Clinical Pharmacology and Therapeutics, 13, 181

Coltart, D. J., and Shand, D. G. (1970). British Medical fournal, 3, 731.

Connolly, C. K., and Batten, J. C. (1970). British Medical fournal, 2, 515. Fitzgerald, J. D., and O'Donnell, S. R. (1971). British fournal of Pharmacology, 43, 222 .

Jones, R. S., Buston, M. H., and Wharton, M. J. (1962). British fournal of Diseases of the Chest, 56, 78.

Kempthorne, O. (1952). The Design and Analysis of Experiments, p. 163. New York, John Wiley and Sons Inc.

Kumana, C. R., and Kaye, C. M. (1974). European fournal of Clinical Pharmacology, 7, 243.

MacDonald, A. G., Ingram, C. G., and McNeill, R. S. (1967). British Fournal of Anaesthesia, 39, 919 .

Marcelle, R., et al. (1968). Acta Allergologica, 23, 11

McNeill, R.' S. (1971). Postgraduate Medical fournal, 47, January Supple-

ment, 14.
Nicolaescu, V., Racoveanu, C., and Manicatide, M. (1973). European fournal of Clinical Pharmacology, 6, 3.

Paterson, J. W., et al. (1970). Pharmacologia Clinica, 2, 127.

Pride, N. B. (1971). British fournal of Diseases of the Chest, 65, 135.

Richardson, P. S., and Sterling, G. M. (1969). British Medical fournal, 3, 143.

Robinson, B. F., et al. (1966). Circulation Research, 19, 400.

Shand, D. G., Nuckolls, E. M., and Oates, J. A. (1970). Clinical Pharmacology and Therapeutics, 11, 112.

Turner, P., et al. (1971). Archives Internationales de Pharmacodynamie et de Thérapie, 191, 104 .

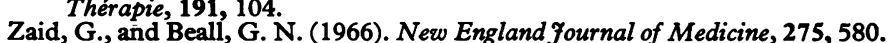

Ziskind, M., et al. (1973). Clinical Pharmacology and Therapeutics, 14, 137.

\title{
Carbohydrate Tolerence and Insulin Responses in Obstructive Jaundice
}

\author{
N. G. SOLER, P. D. EXON, A. PATON
}

British Medical fournal, 1974, 4, 447-449

\section{Summary}

Twenty-three patients with obstructive jaundice were given a 50-g oral glucose tolerance test (G.T.T.) and an insulin stimulation test with oral glucose and intravenous tolbutamide and glucagon. An abnormal glucose response was as common in patients with carcinoma of the pancreas (seven out of 12) as in patients with "other" causes of obstructive jaundice (six out of 11). Though both groups had a low and delayed insulin response the insulin levels were significantly lower in patients with carcinoma of the pancreas. After the insulin stimulation test patients with obstructive jaundice who did not have carcinoma of the pancreas had a greater and significantly different insulin response from patients with pancreatic cancer. There was, however, considerable overlapping between the results of individual patients in the two groups.

\section{Introduction}

Obstructive jaundice may present a difficult diagnostic problem. Clinical, biochemical, and radiological studies may not

Dudley Road Hospital, Birmingham B18 7 QH

N. G. SOLER, M.D., M.R.C.P., Senior Registrar

P. D. EXON, M.B., M.R.C.P., Sheldon Research Fellow

A. PATON, M.D., F.R.C.P., Consultant Physician identify the cause of the jaundice and a diagnosis is often reached only at laparotomy (Knill-Jones et al., 1973). Gall stones and carcinoma of the pancreas account for most cases but various other conditions such as drug-induced cholestasis or hepatitis may be responsible. Abnormal glucose tolerance has been reponted in $37 \%$ to $50 \%$ of patients with carcinoma of the pancreas (Murphy and Smith, 1963; Braganza and Howat, 1972) while ot her workers have shown a flat insulin response to glucose (McKiddie et al., 1969). According to Malins (1968) and Truelove and Reynell (1972) glycosuria and an abnormal glucose tolerance in a patient with obstructive jaundice favour a diagnosis of carcinoma of the pancreas.

Oral glucose tolerance and insulin responses have been studied in patients with obstructive jaundice due to various causes, before the diagnosis was established, to assess their predictive value. We have also used intensive pancreatic $\beta$ cell stimulation with glucose, tolbutamide, and glucagon to investigate whether insulin reserves in patients with carcinoma of the pancreas differ from those in other patients with obstructive jaundice.

\section{Patients and Methods}

Twenty-three patients with clinical and biochemical evidence of obstructive jaundice were studied (table I). A definite cause of the jaundice was later diagnosed at laparotomy in 20 patients. Of these, 12 had a carcinoma of the pancreas (half involving the head and half both the head 